\title{
Sistem Informasi Geografis Tempat Pembuangan Sampah Berbasis Android Di Kota Gorontalo
}

\author{
Alang $^{1}$, Hariati Husain ${ }^{2}$ \\ 1 e-mail: alang.research@gmail.com,2, hariatihusain1405@gmail.com, \\ ${ }^{1}$ Teknik Elektro, Universitas Ichsan Gorontalo, \\ ${ }^{2}$ Informatika, Universitas Ichsan Gorontalo.
}

\begin{abstract}
The population of Gorontalo city is likely to increase because it is the provincial capital which is the center of economy and business. The increasing number of people is increasing the potential for landfill. some people who are less aware of cleanliness will dispose of garbage indiscriminately if they do not know the nearest landfill from their home. Garbage buildup will pollute the environment so that it can interfere with public health and can also cause problems in the future such as flood disasters. Today's problems are often solved by the use of technology, especially information and communication technology. Waste processing can most likely be overcome by using information and communication technology through high mobility media such as smartphones. Today's thriving smartphones are smartphones with android operating systems. Android smartphones besides having high mobility, also have very useful features such as google maps and GPS. Google maps and GPS features can collaborate in an android app program creation. Application program creation is designed using android and PHP programming languages collaborated with MySQL databases as data container media. The application program will be made reliable to solve the problem of waste processing by utilizing Google maps as a means to see landfills (TPS) and GPS as a means to detect the position of people or places that have garbage. Designed applications are expected to provide information on the nearest landfill (TPS) in the area where people live so that there is no garbage buildup, problems in the future such as health problems and flooding
\end{abstract}

Keywords—TPS, Geographic information systems, Android.

Intisari- Jumlah penduduk kota Gorontalo kemungkinan besar akan semakin meningkat dikarenakan merupakan ibu kota provinsi yang merupakan pusat ekonomi dan bisnis. Meningkatnya jumlah penduduk maka semakin meningkat potensi penimbunan sampah perkapita. sebagian masyarakat yang kurang sadar akan kebersihan akan membuang sampah secara sembarangan apabila belum mengetahui tempat pembuangan sampah yang terdekat dari rumahnya. Penumpukan sampah akan mencemari lingkungan sehingga dapat mengganggu kesehatan masyarakat dan dapat pula menimbulkan masalah dikemudian hari seperti bencana banjir. Permasalahan yang terjadi dimasa sekarang sering diselesaikan dengan penggunaan teknologi khususnya teknologi informasi dan komunikasi. Pengolahan sampah kemungkinan besar dapat diatasi dengan menggunakan teknologi informasi dan komunikasi melalui media yang punya mobilitas tinggi seperti smartphone. Smartphone yang berkembang dimasa sekarang ialah smartphone bersistem operasi android. Smartphone android disamping punya mobilitas tinggi, juga memiliki fitur-fitur yang sangat berguna seperti google maps dan GPS. Fitur Google maps dan GPS dapat dikolaborasikan dalam sebuah pembuatan program aplikasi android. Pembuatan program aplikasi dirancang menggunakan Bahasa pemrograman android dan PHP yang dikolaborasikan dengan database MySQL sebagai media penampung data. Program aplikasi yang akan dibuat dapat diandalkan untuk mengatasi permasalahan pengolahan sampah dengan memanfaatkan google maps sebagai sarana untuk melihat tempat pembuangan sampah (TPS) dan GPS sebagai sarana untuk mendeteksi posisi orang atau tempat yang memiliki sampah. aplikasi yang dirancang diharapkan dapat memberikan informasi tempat pembuangan sampah terdekat (TPS) yang ada diwilayah tempat tinggal masyarakat sehingga tidak terjadi penumpukan sampah, masalah dikemudian hari seperti gangguan kesehatan dan banjir

Kata Kunci- TPS, Sistem Informasi Geografis, Android 


\section{PENDAHULUAN}

Permasalahan sampah pada umumnya diketahui pada daerah perkotaan khususnya ibukota provinsi. Hal ini terjadi seiring meninggkatnya jumlah penduduk, diikuti oleh peningkaatn pendapatan,perubahan pola konsumsi pertumbuhan ekonomi, serta urbanisasi dan industrial sehinga mengakibatkan meningkatnya potensi timbunan sampah perkapita dan beragam jenis sampah yang dihasilkan(1). Kota Gorontalo merupakan ibu kota dari provinsi Gorontalo yang memiliki tingkat kepadapatan penduduk yang cukup tinggi dibanding daerah lain di provinsi Gorontalo. Permasalahan pengolahan sampah di kota Gorontalo masih tahap aman hingga saat ini dan belum bisa disetarakan dengan kota besar yang lainnya yang memiliki permasalahan pengolahan sampah.

Dimasa mendatang, jumlah penduduk kota Gorontalo kemungkinan besar akan semakin meningkat dikarenakan merupakan ibu kota provinsi yang merupakan pusat ekonomi dan bisnis. Meningkatnya jumlah penduduk maka semakin meningkat potensi penimbunan sampah perkapita. Tempat pengumpulan sampah sementara (TPS) telah disediakan oleh pemerintah kota Gorontalo, akan tetapi masih ada masyarakat yang belum mengetahui lokasinya. sebagian masyarakat yang kurang sadar akan kebersihan akan membuang sampah secara sembarangan apabila belum mengetahui tempat pembuangan sampah yang terdekat dari rumahnya. Masyarakat yang memiliki bertempat tinggal yang jauh dari TPS dan memiliki kesibukan yang cukup padat, tidak memiliki kesempatan untuk membuang sampah pada tempat yang sediakan dan lebih memilih untuk berlangganan pada petugas pengumpul sampah yang berada disekitaran tempat tinggalnya. Tidak menentunya jadwal pengambilan sampah oleh petugas mengakibatkan terjadinya penumpukan sampah yang cukup lama. Penumpukan sampah akan mencemari lingkungan sehingga dapat mengganggu kesehatan masyarakat dan dapat pula menimbulkan masalah dikemudian hari seperti bencana banjir.

Permasalahan yang terjadi dimasa sekarang sering diselesaikan dengan penggunaan teknologi khususnya teknologi informasi dan komunikasi. Pengolahan sampah kemungkinan besar dapat diatasi dengan menggunakan teknologi informasi dan komunikasi melalui media yang punya mobilitas tinggi seperti smartphone. Smartphone yang berkembang dimasa sekarang ialah smartphone bersistem operasi android. Smartphone android sudah hampir sebagian besar telah dimiliki oleh masyarakat khususnya masyarakat perkotaan. Smartphone android disamping punya mobilitas tinggi, juga memiliki fitur-fitur yang sangat berguna seperti google maps dan GPS. Google maps memungkinkan seseorang mampu melihat peta dari sebuah wilayah atau lokasi sedangkan GPS mampu mendeteksi posisi atau koordinat tempat kita berada. Fitur Google maps dan GPS dapat dikolaborasikan dalam sebuah pembuatan program aplikasi android. Program aplikasi yang akan dibuat diharapkan dapat memberikan informasi tempat pembuangan sampah terdekat (TPS) yang ada diwilayah tempat tinggal masyarakat sehingga tidak terjadi penumpukan sampah, masalah dikemudian hari seperti gangguan kesehatan dan banjir.

\section{TUJUAN PENELITIAN}

Tujuan dalam penelitian ini adalah Membuat sebuah program aplikasi yang mampu memberikan informasi tempat pembuangan sampah terdekat (TPS) yang ada diwilayah tempat tinggal masyarakat.

\section{METODE PENELITIAN}

\section{Metode Penelitian}

Adapun metode yang digunakan dalam analisis sistem adalah metode rekayasa perangkat lunak dengan model prototipe (Prototyping Model). Model ini bertujuan untuk membuat ptototipe dari perangkat lunak yang akan dibuat. Dalam [9], menyatakan bahwa sering pelanggan (costumer) membayangkan kumpulan kebutuhan yang di inginkan tapi tidak terspesifikasikan secara detail dari segi masukan (input), proses maupun keluaran (output). Model prototipe dapat digunakan untuk memastikan efisiensi algoritma dan kemampuan penyesuaian dari Sistem Operasi dan bentuk-bentuk yang harus dilakukan terhadap antarmuka suatu sistem. Model Prototipe dapat dilihat pada gambar dibawah ini.

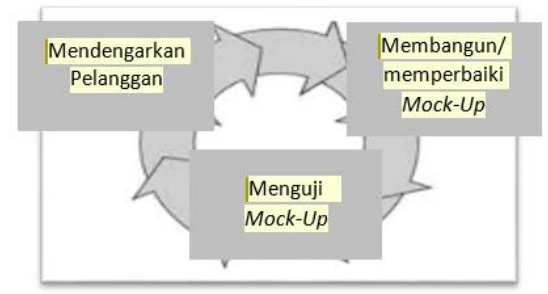

Gambar. Ilustrasi Model Prototipe 


\section{Data TPS (Tempat Pembuangan Sampah)}

Lokasi TPS yang berhasil dikumpulkan saat melakukan survey. Berikut adalah data TPS secara detail.

Tabel 1 Data TPS

\begin{tabular}{|c|c|c|c|c|c|}
\hline No. & Alamat TPS & Kecamatan & kapasitas & latitude & longitude \\
\hline 1 & J1. Letjend Suprapto No.2, Biawao & Kota Selatan & $2 \mathrm{M}^{3}$ & 0.533188 & 123.057688 \\
\hline 2 & Jl. Sultan Hasanuddin No.16, Biawao & Kota Selatan & $1 \mathrm{M}^{3}$ & 0.532444 & 123.058005 \\
\hline 3 & Jl. Sutoyo No.108, Biawao & Kota Selatan & $3 \mathrm{M}^{3}$ & 0.535727 & 123.059602 \\
\hline 4 & Jl. K.H. Ahmad Dahlan No.1, Limba U & Kota Selatan & $1 \mathrm{M}^{3}$ & 0.541706 & 123.062343 \\
\hline 5 & $\begin{array}{l}\text { Jl. Dr. Hi. Medi Botutihe SE No.34, } \\
\text { Heledulaa Selatan }\end{array}$ & Kota Timur & $1 \mathrm{M}^{3}$ & 0.541061 & 123.063918 \\
\hline 6 & Jl. Rajawali No.6, Heledulaa Selatan & Kota Timur & $1 \mathrm{M}^{3}$ & 0.540813 & 123.065590 \\
\hline 7 & $\begin{array}{l}\text { Jl. Jaksa Agung Suprapto No.5, Limba U } \\
\text { Dua }\end{array}$ & Kot & $2 \mathrm{M}^{3}$ & 0.544325 & 123.056820 \\
\hline 8 & $\begin{array}{l}\text { Jl. Drs. Achmad Nadjamuddin, Limba U } \\
\text { Dua }\end{array}$ & Kota Selatan & $3 \mathrm{M}^{3}$ & 0.552356 & 123.055723 \\
\hline 9 & J1. Jeruk No.78 Huangobotu & Dungingi & $2 \mathrm{M}^{3}$ & 0.563138 & 123.040190 \\
\hline 10 & Jl. Palu No.46, Liluwo & Kota Tengah & $1 \mathrm{M}^{3}$ & 0.564738 & 123.052356 \\
\hline 11 & Jl. Manado, Pulubala & Kota Tengah & $1 \mathrm{M}^{3}$ & 0.566696 & 123.054917 \\
\hline 12 & Jl. Rusli Datau, Tanggikiki & Sipatana & $2 \mathrm{M}^{3}$ & 0.572438 & 123.070420 \\
\hline 13 & Jl. Taman Pendidikan no.36, Moodu & Kota Timur & $1 \mathrm{M}^{3}$ & 0.542110 & 123.073562 \\
\hline 14 & Jl. Profesor DR. H. Aloei Saboe, Limba & Kota Utara & $1 \mathrm{M}^{3}$ & 0.546212 & 123.079600 \\
\hline 15 & Jl. Taman Surya No.16, Dembe dua & Kota Utara & $1 \mathrm{M}^{3}$ & 0.549713 & 123.079011 \\
\hline 16 & Jl. KH Adam Zakaria No.89, Wongkaditi & Kota Utara & $1 \mathrm{M}^{3}$ & 0.557451 & 123.074276 \\
\hline 17 & Jl. Pangeran Hidayat No.18, Wamialo & Kota Tengah & $2 \mathrm{M}^{3}$ & 0.553444 & 123.064241 \\
\hline 18 & $\begin{array}{l}\text { Jl. Arif Rahman Hakim No.34, Dulalowo } \\
\text { Timur }\end{array}$ & Kota Tengah & $2 \mathrm{M}^{3}$ & 0.557476 & 123.058554 \\
\hline 19 & Jl.Kalimantan No.30, Dulalowo Timur & Kota Tengah & $2 \mathrm{M}^{3}$ & 0.560204 & 123.055448 \\
\hline 20 & Jl. Sulawesi No.61 & Kota Tengah & $0.5 \mathrm{M}^{3}$ & 0.559831 & 123.050718 \\
\hline 21 & J1. Prof.Dr. H.B. Jassin No.540, Liluwo & Kota Tengah & $1 \mathrm{M}^{3}$ & 0.565462 & 123.047407 \\
\hline 22 & Jl. Selayar No.140 A, Paguyaman & Kota Tengah & $0.5 \mathrm{M}^{3}$ & 0.572228 & 123.052114 \\
\hline 23 & Jl. Ternate No.12, Tapa & Sipatana & $1 \mathrm{M}^{3}$ & 0.574824 & 123.052971 \\
\hline
\end{tabular}

\section{Tahapan Analisis Pembuatan Sistem}

Didalam pembuatan system menggunakan metode prototipe dibutuhkan data-data pendukung yang diperole dengan pengumpulan data yang relevan dan sesuai dengan kebutuhan sistem yang akan dibangun. Metode-metode pengumpulan data yang di gunakan yaitu :

a. Metode observasi.

Metode observasi yang dilakukan pada penelitian ini yaitu peninjauan lansung ke tempat pembuangan sampah (TPS) yang ada di kota gorontalo untuk pengambilan data berupa gambar, jenis tempat sampah dan titik koordinat.

b. Metode wawancara

Wawancara dilakukan untuk mengetahui informasi-informasi lebih mendalam langsung dari dinas lingkungan hidup sehingga peneliti dapat mengetahui apa saja yang dibutuhkan untuk pengembangan sistem yang akan dibuat dan disesuaikan dengan kebutuhan.

c. Metode dokumentasi

Dokumentasi merupakan pengumpulan data dimana dalam penelitiaan ini data yang digunakan yaitu data berupa gambar dan koordinat dari tempat pembuangan sampah. 


\section{ANALISIS DAN DESAIN SISTEM}

\section{Analisa Sistem yang diusulkan}

Sistem yang diusulkan digambarkan dengan usecase diagram di bawah ini.

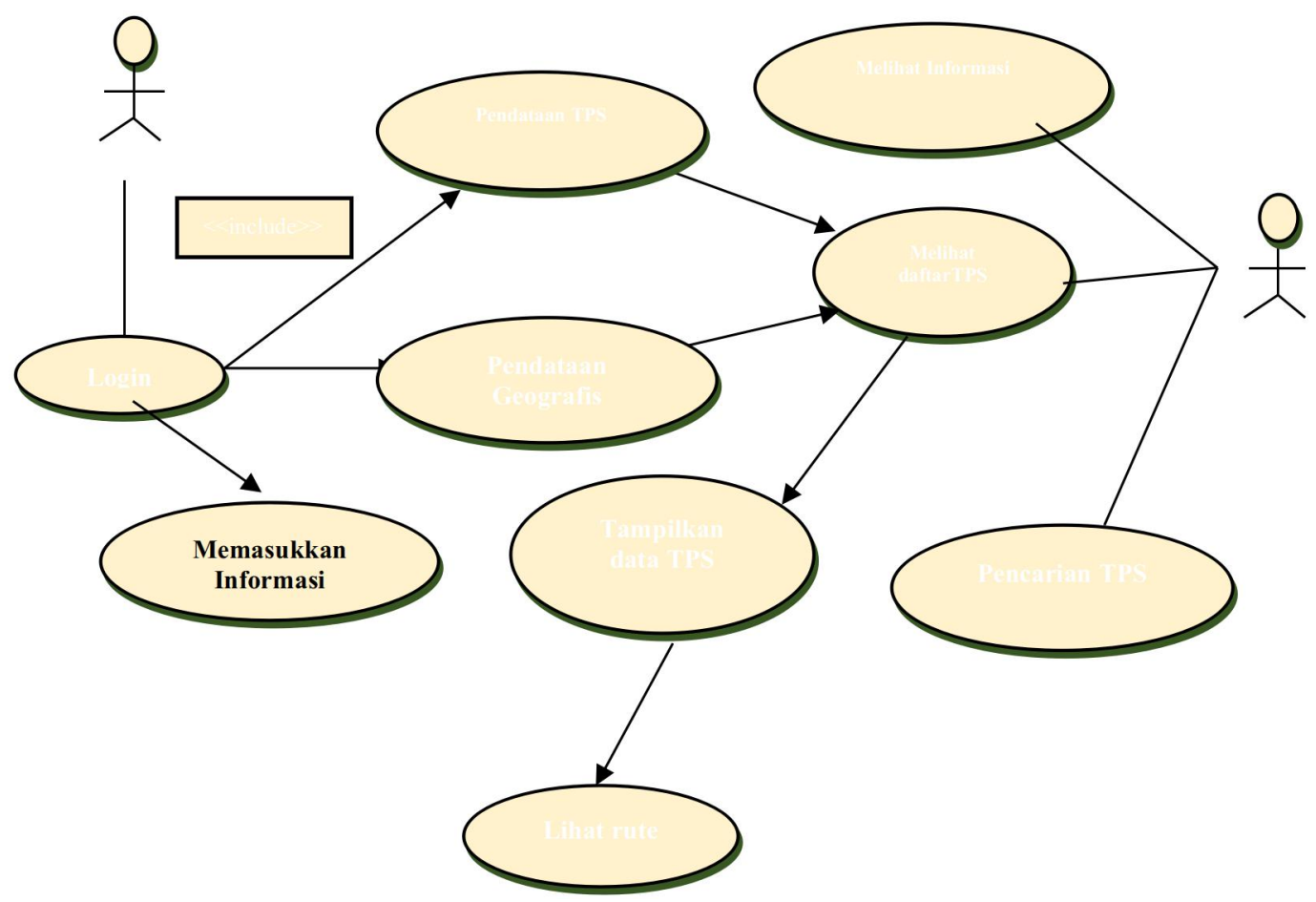

Gambar 4.1 Sistem yang diusulkan

\section{Analisis Sistem}

Sistem yang dirancang memiliki 2 aktor yaitu pegawai dinas lingkungan hidup selaku admin dan masyarakat selaku user. admin melakukan pengelolaan data lokasi TPS dan data Armada Kebersihan berserta dengan data jalur layanan. Admin juga mengelola data informasi serta mengelola data pengaduan dari masyarakat. masyarakat dapat mencari lokasi TPS serta melihat rute menuju ke lokasi TPS tersebut. masyarakat juga dapat melihat armada kebersihan beserta dengan jalur layanan yang dilewati oleh armada tersebut. System yang dirancang juga memungkinkan masyarakat menyampaikan pengaduan dan juga melihat informasi terkait dengan dinas lingkungan hidup. Sistem yang dirancang dilengkapi fitur bantuan apabila masyarakat mengalami kesulitan dalam mengoperasikannya.

\section{Perancangan Interface}

Tampilan sistem pada server rancang sangat sederhana, sedangkan tampilan sistem yang berjalan di client dirancangan dengan mengoptimalkan kemudahan pengguna. Berikut merupakan tampilan Graphic User Interface dari sistem yang diusulkan :

Pada tahap perancangan interface terdapat 2 jenis interface yang akan dibuat yaitu interface untuk admin dan interface untuk masyarakat. Berikut uraian dari masing-masing interface.

\section{a. Interface admin}

Interface pada sisi admin berupa tampilan input data TPS, data Armada dan data Jalur. Berikut gambar dari masingmasing interface. 


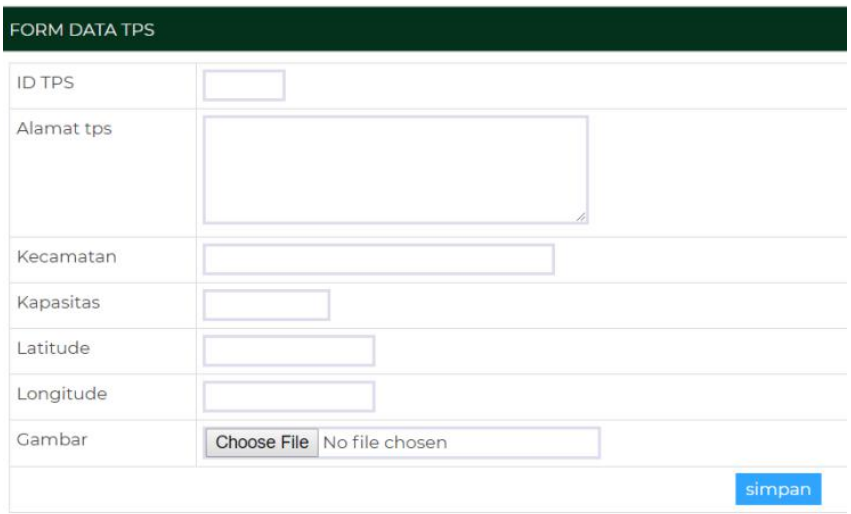

Gambar 4.2 Desain interface data TPS

Desain interface data TPS berfungsi untuk tampilan penginputan data TPS ke dalam sistem

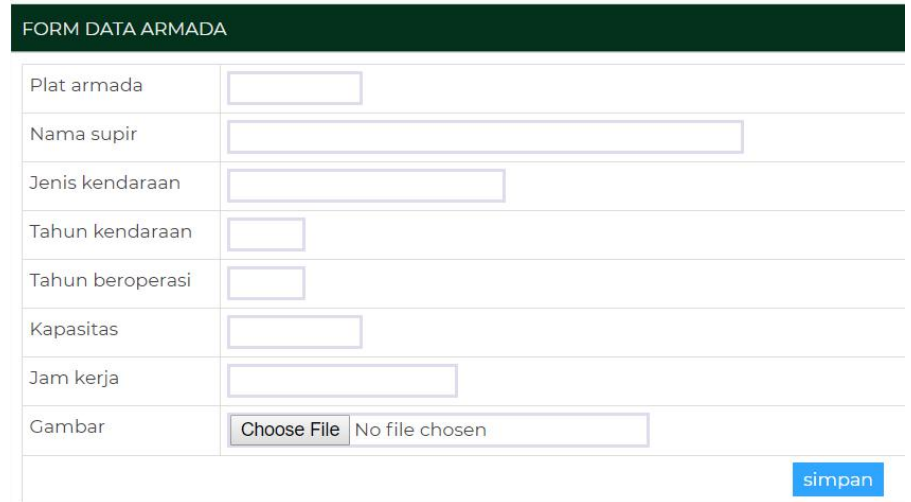

Gambar 4.3 Desain interface data armada

Desain interface data Armada berfungsi untuk tampilan penginputan data Armada ke dalam sistem.

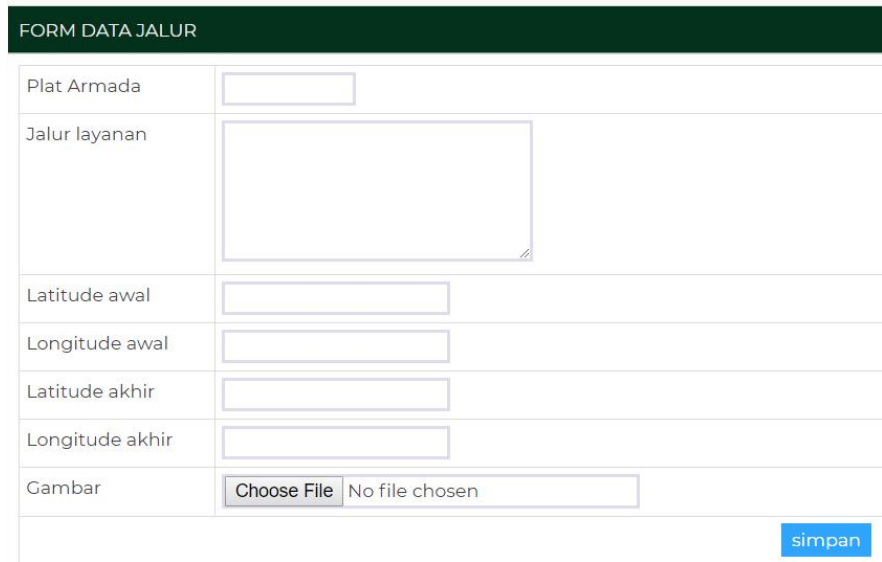

Gambar 4.4 Desain Interface Data Jalur

Desain interface data jalur berfungsi untuk tampilan penginputan data jalur armada ke dalam sistem.

\section{b. Interface User / Masyarakat}

Interface user yang dirancang pada sisi user / masyarakat terdiri dari 5 tampilan yaitu tampilan menu, daftar armada, data detail armada, data TPS, dan data detail TPS. 


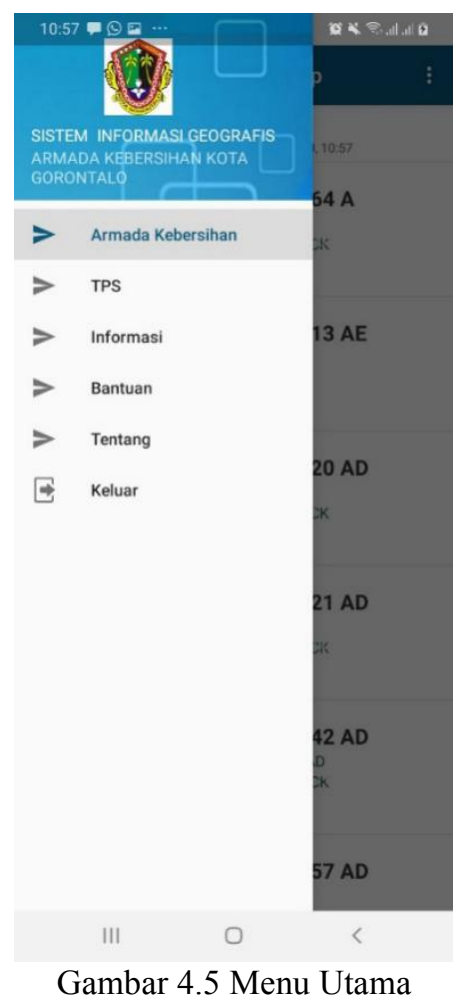

Menu Utama berfungsi sebagai navigasi menuju ke halaman lain dari aplikasi.

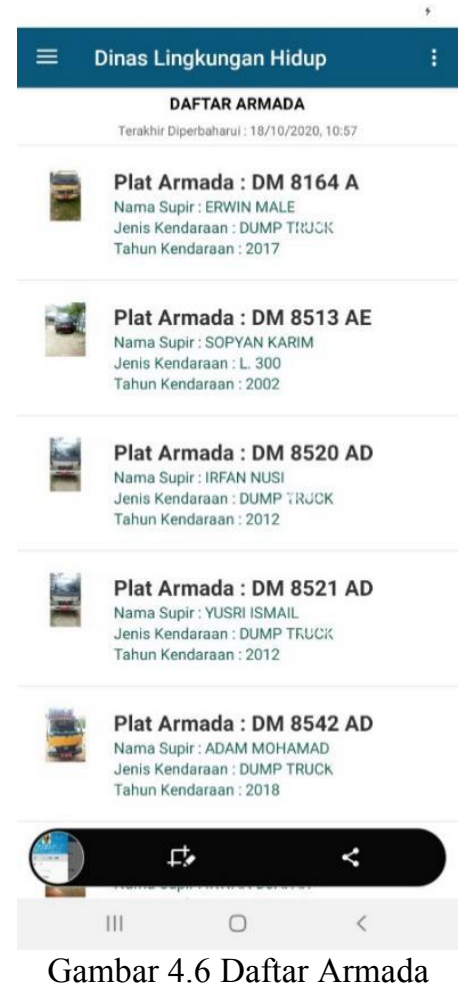

Tampilan daftar armada berfungsi untuk melihat data armada yang telah diinput oleh administrator dan berfungsi untuk memilih armada yang diingin diliat informasinya. 


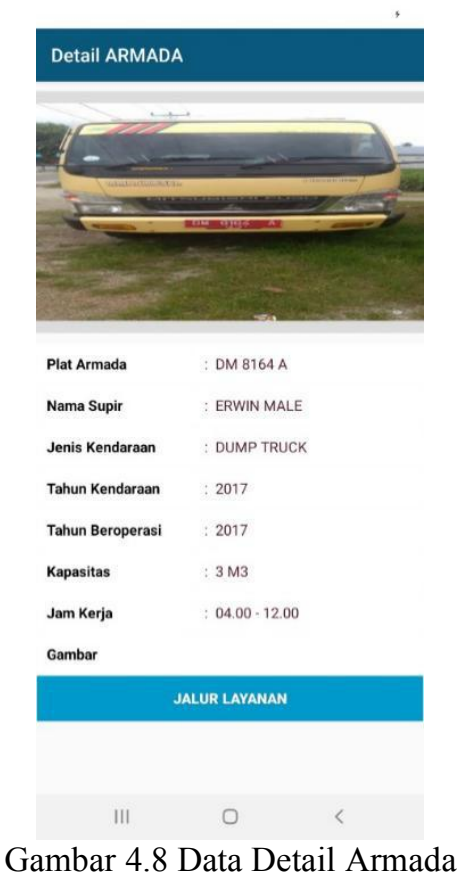

Tampilan data detail armada berfungsi untuk menampilkan data detail dari armada kebersihan.

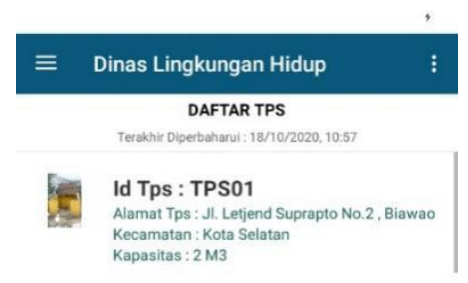

Id Tps: TPSO2

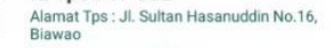

Kecamatan : Kota Selatan

Kecamatan : Kota Selata
Kapasitas : 1 M3

\section{III \\ Gambar 4.9 Daftar TPS}

Daftar TPS berfungsi untuk melihat daftar TPS yang telah dimasukkan ke dalam system. 


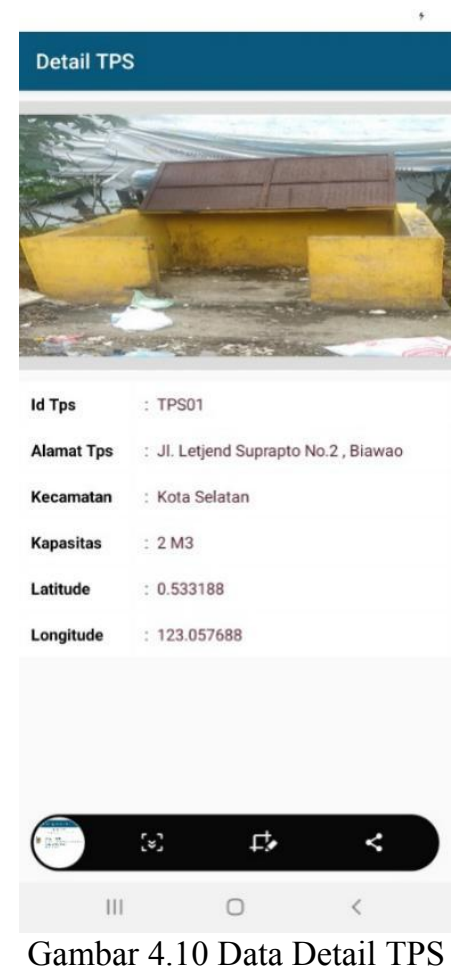

Data Detail TPS berfungsi untuk melihat informasi detail dari masing-masing data TPS.

\section{KESIMPULAN}

Hasil dalam penelitian ini telah diimplementasikan dan telah melalui uji white box dan blackbox sebelum diterapkan pada lokasi penelitian. Setelah adanya penerapan aplikasi system informasi Geografis maka pemantauan lebih mudah dilakukan dan masalah penanganan sampah dapat teratasi sesuai dengan tujuan penelitian selama ini.

\section{SARAN}

Aplikasi ini masih jauh dari sempurna sehingga membutuhkan banyak pengembangan untuk kedepannya, maka disarankan untuk penelitian berikutnya untuk menambahkan fitur-fitur yang mempermudah user dalam melaksanakan tugasnya misalnya seperti fitur pengaduan dan uplod foto sebagai bukti dari pelaporan masyarakat.

\section{REFERENSI}

[1] Nguyen dan Schnitzer, 2009, Sustainable Solutions for Solid Waste Management in South East Asian Countries, Sciencedirect.

[2] Purnama, Fitri.,2013, Sistem Pengelolaan Sampah Dengan Memanfaatkan Sistem Informasi Geografis (Sig), Jurnal Ilmiah Universitas Tanjungpura.

[3] Aini, A. 2012. Sistem Informasi Geografis. Yogyakarta: STIMIK AMIKOM Yogyakarta.

[4] Suprianto, D., \& Agustin, R. 2012. Pemrograman Aplikasi Android. Yogyakarta: MediaKom.

[5] Sucita, Agus, 2012 "Pembangunan Sistem Aplikasi Layanan Berbasis Lokasi Pencarian ATM dan POM Bensin Terdekat Berbasis Android", STMIK AMIKOM, Yogyakarta.

[6] Elian. 2012. Layanan informasi Google maps. Semarang

[7] Safaat. (2012). Pemrograman Aplikasi Mobile Smartphone dan Tablet PC. Bandung: Informatika Bandung.

[8] Kasiman, P. 2006. Aplikasi Web dengan PHP dan MySQL,. Yogyakarta: Andi Offset.

[9] Rosa, A., \& Shalahuddin, M. 2013. Rekayasa Perangkat Lunak. Bandung: Informatika Bandung

[10] Pressman, R. 2012. Software Engineering: A Practitioner's Approach Seventh Edition. New York: McGraw Hill

[11] Sadeli, Muhammad, 2014. Toko Buku Online dengan Android. Palembang, Indonesia: Maxikom

[12] Santoso, K. Imam, Rais, M. Nur, 2015. Implementasi Sistem Informasi Geografis Daerah Pariwisata Kabupaten Temanggung Berbasis Android dengan Global Positioning. 